\title{
KOMUNITAS IKAN DI SUNGAI JEROWAN KABUPATEN MADIUN
}

\section{The Fish Community in Jerowan River, Madiun District}

\author{
Nanik Retno Buwono ${ }^{1 *}$, Fariedah F. ${ }^{2}$ dan Rizki Eka Anestyaningrum ${ }^{3}$ \\ ${ }^{1}$ Dosen Program Studi Manajemen Sumberdaya Perairan \\ ${ }^{2}$ Dosen Program Studi Budidaya Perairan \\ ${ }^{3}$ Mahasiswa Program Studi Manajemen Sumberdaya Perairan \\ *buwonoretno@ub.ac.id
}

\begin{abstract}
Abstrak
Sungai Jerowan merupakan anak sungai Bengawan Solo yang digunakan oleh masyarakat dalam aktivitas bidang pertanian maupun perikanan. Selain itu pada beberapa titik masih terdapat masyarakat yang menggunakan sungai tersebut untuk melakukan kegiatan MCK dan pembuangan limbah rumah tangga, peternakan dan pertanian yang mengakibatkan bertambahnya beban pencemar di air sungai. Studi komunitas ikan diperlukan sehubungan dengan kondisi perairan Sungai Jerowan sebagai aspek pengelolaan sumber daya. Tujuan penelitian ini adalah untuk mengetahui keanekaragaman dan jenis sebaran dari ikan di daerah aliran Sungai Jerowan. Dengan menggunakan metode survei yang dilakukan pada tiga stasiun dengan tiga kali ulangan. Hasil penelitian menunjukkan hasil komposisi dari ikan yang ditemukan di Sungai Jerowan terdiri dari terdiri atas 6 spesies yaitu ikan Betok (Anabas testudineus), ikan Belanak (Liza subviridis), ikan Keting (Mystus micrachantus), ikan Wader (Rasbora argyrotaenia), ikan Sepat Siam (Trichogaster pectoralis), ikan Gatul (Gambusia affinis). Stasiun 1 memiliki nilai keanekaragaman rendah dan pola sebaran ikan termasuk pemencaran individu yang cenderung acak, stasiun 2 memiliki nilai keanekaragaman rendah dengan pola sebaran termasuk pemencaran individu yang cenderung berkelompok dan stasiun 3 memiliki nilai keanekaragaman rendah dengan pola sebaran termasuk pemencaran individu yang cenderung merata. Nilai parameter kualitas air pada setiap stasiun dapat dikatakan layak untuk pertumbuhan dan kehidupan ikan.
\end{abstract}

Kata Kunci: Komunitas Ikan, Sungai Jerowan, Kualitas Air

\begin{abstract}
The Jerowan River is a tributary of Bengawan Solo that is used by the community in agricultural and fisheries activities. In addition, at some points there are still people who use these rivers to perform toilet activities and disposal of household waste, agricultural waste resulting in increased pollutant loads in river water. Fish community studies are needed in connection with the waters of the Jerowan River as an aspect of resource management. The purpose of this research is to know the diversity and the type of distribution of fish in the Jerowan River. Using survey method conducted on three stations with three replications. The results showed that the composition of fish found in Jerowan River consisted of 6 species of Anabas testudineus (Betok), Liza subviridis (Belanak), Mystus micrachantus (Keting), Rasbora argyrotaenia (Wader), Trichogaster pectoralis (Sepat Siam), Gambusia affinis (Gatul). Station 1 has low biodiversity value and fish distribution pattern including individual dispersion which tend to be random, station 2 has low diversity value with spreading pattern including individual dispersion which tend to cluster and station 3 has low diversity value with spread pattern including individual dispersion which tend to be evenly distributed. The value of water quality parameters at each station can be said to be feasible for growth and fish life
\end{abstract}

Keywords: The Fish Community, Jerowan River, Water Quality

\section{PENDAHULUAN}

Seiring dengan pertumbuhan populasi manusia, daerah bantaran sungai banyak digunakan untuk pemukiman, lahan pertanian, bahkan industri. Secara fungsional sungai merupakan tempat penyimpanan dan penyedia air, media transportasi, sumber makanan, tempat pembuangan limbah dalam kapasitas tertentu (Septiano, 2006). Penggunaan bantaran sungai yang tidak sesuai dapat menyebabkan timbulnya masalah kritis persediaan air bukan hanya dari segi kuantitas namun juga dari segi kualitas.yang tidak hanya dapat mengganggu kehidupan makhluk hidup di darat tetapi juga ber- 
pengaruh sacara langsung terhadap komunitas ikan yang ada dalam perairan sungai. Sungai Jerowan merupakan anak sungai Bengawan Solo. Selain menjadi sarana untuk irigasi areal persawahan, Sungai Jerowan setiap harinya didatangi banyak orang yang ingin memancing ikan, selain itu pada beberapa titik masih terdapat masyarakat yang menggunakan Sungai Jerowan untuk melakukan kegiatan MCK dan pembuangan limbah baik limbah rumah tangga maupun limbah pertanian. Menurut Peraturan Gubernur Jawa Timur No. 61 Tahun 2010, Sungai Jerowan digolongkan ke dalam kelas III, yakni badan air yang peruntukkannya digunakan untuk pembudidayaan ikan air tawar, peternakan, irigasi, dan yang semacamnya.

Beberapa studi komunitas ikan telah dilakukan di beberapa tempat, akan tetapi penelitian ini belum pernah dilakukan di Sungai Jerowan dan secara umum penelitian yang terpublikasi masih dianggap sangat kurang. Sehingga diharapkan penelitian ini akan memberikan informasi yang bermanfaat bagi pengelolaan Sungai Jerowan. Tujuan penelitian ini adalah untuk mengetahui keanekaragaman dan jenis sebaran dari ikan di daerah aliran Sungai Jerowan.

\section{METODOLOGI}

\section{Waktu dan Tempat}

Penelitian ini dilakukan di daerah aliran Sungai Jerowan Kecamatan Mejayan Kabupaten Madiun. pada bulan Mei 2016-Juli 2016.

\section{Materi Penelitian}

Peralatan Penelitian

Peralatan yang digunakan dalam penelitian ini adalah termometer $\mathrm{Hg}$, stopwatch, tali raffia, botol air mineral, secchidisk, penggaris, kotak standart $\mathrm{Ph}$, botol DO $250 \mathrm{ml}$, pipet tetes, statif, biuret, beaker glass, erlenmeyer, corong, pipet volume $100 \mathrm{ml}$, washing bottle, hot plate, gelas ukur $100 \mathrm{ml}$, bola hisap, spektrofotometer, toples, section set, papan pengukur dan kertas label.

\section{Bahan Penelitian}

Bahan yang digunakan dalam penelitian ini adalah ikan yang diperoleh dari sampling, air sungai, $\mathrm{pH}$ paper, $\mathrm{MnSO}_{4}, \quad \mathrm{NaOH}+\mathrm{KI}, \quad \mathrm{H}_{2} \mathrm{SO}_{4}$, amilum, $\mathrm{N}_{2} \mathrm{~S}_{2} \mathrm{O}_{3}, \quad \mathrm{KMnO}_{4}, \mathrm{H}_{2} \mathrm{SO}_{4}, \quad$ Na-oxallat, akuades, tissue dan formalin.

\section{Metode Penelitian}

Metode yang digunakan pada penelitian ini adalah dengan metode survei yaitu suatu usaha untuk mengumpulkan data dari anggota populasi untuk menentukan status sekarang dari populasi itu mengenai satu variabel atau lebih. (Darmadi, 2011). Dalam penelitian ini survei dilakukan secara langsung dengan mendatangi lokasi aliran Sungai Jerowan guna mengetahui kondisi lapang secara langsung. Kondisi lapang yang dimaksud adalah keadaan sungai atau gejala-gejala yang nantinya akan membantu dalam pengumpulan data yang telah dirumuskan sebelumnya, serta kondisi dan aktivitas masyarakat di sekitar aliran sungai.

\section{Prosedur Kerja}

Pengambilan sampel ikan dan kualitas air dilakukan di tiga stasiun. Penentuan stasiun didasarkan pada penggunaan daerah di sekitar sungai. Berdasarkan pertimbangan tersebut dan hasil pengamatan di lapang, stasiun yang ditentukan yakni (lihat gambar 1):

- Stasiun I : daerah banyak terdapat naungan pepohonan, terletak di Desa Mejayan

- Stasiun II : daerah pemukiman penduduk, terletak di Desa Bangunsari

- Stasiun III : daerah dengan tata guna lahan pertanian, terletak di Desa Bajulan

Metode pengambilan sampel ikan diambil dengan menggunakan alat tangkap pancing, serok dan jaring. Selanjutnya jenis ikan yang tertangkap didokumentasikan dengan kamera digital kemudian diawetkan dengan formalin 4\%. Sampel ikan dibawa ke laboratorium Hidrobiologi Fakultas Perikanan dan Ilmu Kelautan 
Universitas Brawijaya untuk diidentifikasi dan selanjutnya ikan-ikan tersebut diamati karakter morfologi dan meristiknya serta diukur karakter morfometriknya. Untuk parameter kuallitas air yang diukur adalah parameter fisika (suhu, arus dan kecerahan) sedangkan parameter kimia yaitu oksigen terlarut, bahan organik total dan $\mathrm{pH}$.

Menurut Suwondo et al.,(2005), rumus kelimpahan relatif (Di) sebagai berikut:

$$
\mathrm{Di}=(\Sigma \mathrm{ni}) / \mathrm{N} \times 100 \%
$$

Keterangan:

Di : Kelimpahan relatif

$\mathrm{Ni}$ : Jumlah organisme yang ditemukan tiap spesies

$\mathrm{N}$ : Jumlah total semua organisme yang ditemukan

Hubungan antara jumlah jenis dengan individu dapat dinyatakan dalam indeks keragaman (Diversity Indeks). Untuk menentukan keanekaragaman ikan digunakan indeks Shannon-Wiener (Brower and Zar, 1990)

$$
H^{\prime}=-\sum_{i=1}^{n}\left(\frac{n i}{N}\right) \log _{2}\left(\frac{n i}{N}\right)
$$

Keterangan :

$\mathrm{H}^{\prime}=$ Indeks Diversitas Shannon-Wiener

$\mathrm{n} \quad=$ Jumlah individu spesies ke-i

$\mathrm{N}$ = Jumlah individu semua spesies

Penentuan kriteria:

$\mathrm{H}^{\prime}<1=$ Keanekaragaman rendah

$1<\mathrm{H}^{\prime}<3=$ Keanekaragaman sedang

$\mathrm{H}^{\prime}>3=$ Keanekaragaman tinggi

Menurut Krebs (1978) dalam Bahri (2006), pola penyebaran dari spesies ikan selama pengamatan dapat dianalisis menggunakan indeks penyebaran atau sering disebut dengan Indeks Sebaran Morisita. Pola penyebaran ini dihitung dengan indeks penyebaran morisita dengan rumus sebagai berikut:

$$
\mathrm{I} \delta=\frac{\Sigma \times 2-\mathrm{N}}{\mathrm{N}(\mathrm{N}-1)} \mathrm{n}
$$

Dimana :

I : Indeks penyebaran / indeks distribusi Morisita

$\mathrm{N}$ : Jumlah total individu dalam spesies yang terdapat dAlams\$persies denbangmenghitung $\mathrm{Ke}$ terdapat dalam $\mathrm{n}$ contoh

$\Sigma X 2$ : Jumlah kuadrat individu per stasiun untuk total stasiun

$\mathrm{N}$ : Jumlah seluruh stasiun pengambilan sampel

Nilai indeks Morisita yang diperoleh diinterprestasikan sebagai berikut:

I $\delta<1$, pemencaran individu cenderung acak

$\mathrm{I} \delta=1$, pemencaran individu bersifat merata

I $\delta>1$, pemencaran individu cenderung berkelompok.

\section{HASIL DAN PEMBAHASAN Stasiun 1}

Stasiun 1 terletak di Desa Mejayan, di sekitar sungai masih banyak terdapat pepohonan yang tumbuh. Tebing sungai berupa tanah dan beberapa bagian berupa beton yang dibuat untuk memperkuat tanah dari bangunan jembatan yang berada di atas sungai. Banyak terdapat tanaman yang berupa semak-semak di sekitar pinggiran sungai. Tipe substrat berlumpur dengan tipe arus lambat. Keadaan airnya keruh dengan warna kecoklatan. Keadaan lingkungan di sekitar sungai dipenuhi seresah dari reruntuhan daun tetapi jarang ditemui sampah dari aktivitas masyarakat.

Ikan yang tertangkap di stasiun 1 selama penelitian sebanyak 23 ekor terdiri dari 5 spesies yaitu Osteochilus hasseltii, Mystus singaringan, Rasbora argyrotaenia, Trichogaster pectoralis, Gambusia affinis dengan presentase $8,69 \%$ dari jenis ikan Liza subviridis (2 individu), 4,35 \% dari jenis ikan Mystus singaringan, Trichogaster pectoralis, Gambusia affinis dimana masing-masing ditemukan 1 individu selama pengamatan. Presentase ter- 
besar 78,2 \% yaitu dari jenis ikan Rasbora argyrotaenia (18 individu). Ikan dari famili cyprinidae ini juga ditemukan dengan presentase terbesar pada dua stasiun lainnya. Hal ini disebabkan karena ikan dari family cyprinidae merupakan ikan yang banyak ditemukan dalam perairan tawar. Djuhanda dalam Sinaga (1995) menyatakan bahwa cyprinidae merupakan family dengan jumlah spesies relatif banyak di perairan tawar. Cyprinidae merupakan suku yang sangat besar dan terdapat hampir di setiap tempat kecuali di daerah Australia, Madagaskar, Selandia baru, dan Amerika selatan (walaupun di beberapa tempat tersebut pernah dilakukan inroduksi). Hasil perhitungan indeks Keanekaragaman Shannon Wiener pada stasiun 1 adalah 0,8. Hal ini menunjukkan bahwa tingkat keanekaragaman ikan di stasiun 1 rendah. Nilai indeks Keanekaragaman (H') dikatakan rendah karena jumlah jenis dan individu relatif sedikit.

Hasil pengukuran struktur komunitas ikan pada stasiun 1 di Sungai Jerowan yang meliputi kelimpahan relatif (KR), Indeks Keanekaragaman (H'), dan Indeks Morisita (I $\delta$ ) dapat dilihat pada Tabel 1.

Tabel 1. Struktur Komunitas Ikan pada Stasiun 1 di Sungai Jerowan

\begin{tabular}{lcccc}
\hline \multicolumn{1}{c}{ Spesies } & $\begin{array}{c}\text { Jumlah } \\
\text { (individu) }\end{array}$ & $\begin{array}{c}\text { KR } \\
(\%)\end{array}$ & $\mathrm{H}^{\prime}$ & $\mathrm{I} \delta$ \\
\hline $\begin{array}{l}\text { Osteochilus } \\
\text { hasseltii }\end{array}$ & 2 & 8,69 & 0,8 & 0,79 \\
$\begin{array}{l}\text { Mystus } \\
\text { singaringan }\end{array}$ & 1 & 4,35 & & \\
$\begin{array}{l}\text { Rasbora } \\
\text { argyrotaenia }\end{array}$ & 18 & 78,2 & & \\
$\begin{array}{l}\text { Trichogaster } \\
\text { pectoralis } \\
\text { Gambusia }\end{array}$ & 1 & 4,35 & \\
$\begin{array}{l}\text { affinis } \\
\text { Jumlah }\end{array}$ & 1 & 4,35 & & \\
\hline
\end{tabular}

Pada stasiun 1 diperkirakan nilai keanekaragaman jenis ikan masih bisa bertambah jika alat tangkap yang digu- nakan lebih banyak dan periode penangkapan yang cukup lama serta tenaga yang professional yang banyak pula. Masih banyaknya pepohonan atau naungan di sekitar sungai pada stasiun 1. juga merupakan faktor yang mempengaruhi jumlah ikan dalam perairan. Namun, karena tingginya laju mortalitas, baik itu mortalitas karena predator maupun mortalitas melalui penangkapan yang banyak terjadi di sekitar sungai menyebabkan keanekaragaman ikan di sungai pada stasiun 1 relatif sedikit. Pola penyebaran ikan di stasiun 1 ini bersifat pemencaran individu yang cenderung acak.

\section{Stasiun 2}

Stasiun 2 terletak di Desa Bangunsari dengan tata guna lahan berupa pemukiman. Tebing sungai berupa tanah dengan pinggiran sungai masih banyak ditumbuhi semak-semak. Tipe substrat berupa lumpur dan di beberapa bagian banyak ditemui batuan padas. Tipe arus cepat serta keadaan airnya jernih kecoklatan. Masih banyak ditemui sampah rumah tangga di dalam perairan sungai dan di daerah sekitar sungai. Hal ini disebabkan karena warga sekitar sering membuang sampah secara langsung ke dalam sungai maupun di daerah sekitar sungai.

Hasil pengukuran struktur komunitas ikan pada stasiun 2 di Sungai Jerowan yang meliputi kelimpahan relatif (KR), Indeks Keanekaragaman (H'), dan Indeks Morisita (I $\delta$ ) dapat dilihat pada Tabel 2.

Tabel 2. Struktur Komunitas Ikan pada Stasiun 2 di Sungai Jerowan

\begin{tabular}{lllll}
\hline Spesies & $\begin{array}{l}\text { Jumlah } \\
\text { (individu) }\end{array}$ & $\begin{array}{l}\text { KR } \\
(\%)\end{array}$ & H' & I \\
\hline $\begin{array}{l}\text { Rasbora } \\
\text { argyrotaenia }\end{array}$ & 11 & 84,6 & 0,99 & 3,17 \\
$\begin{array}{l}\text { Gambusia } \\
\text { affinis }\end{array}$ & 2 & 15,4 & & \\
Jumlah & 13 & & & \\
\hline
\end{tabular}


Ikan yang tertangkap di stasiun 2 selama penelitian sebanyak 13 ekor terdiri dari 2 spesies yaitu Rasbora argyrotaenia dan Gambusia affinis dengan presentase terbesar 84,6\% dari jenis ikan Rasbora argyrotaenia (11 individu) dan 15,4\% dari jenis ikan Gambusia affinis (2 individu). Ikan dari family cyprinidae seperti Rasbora argyrotaenia masih banyak ditemukan di stasiun 2 hal ini disebabkan ikan dari family cyprinidae merupakan ikan yang banyak ditemukan di perairan tawar. Hasil perhitungan indeks Keanekaragaman Shannon Wiener pada stasiun 2 adalah 0,99. Hal ini menunjukkan bahwa tingkat keanekaragaman ikan di stasiun 2 rendah. Hal ini disebabkan karena masih banyaknya aktivitas masyarakat yang menggunakan perairan sungai untuk kegiatan MCK selain itu banyak masyarakat yang membuang limbah rumah tangga ke dalam perairan sungai sehingga mempengaruhi kehidupan ikan. Pola penyebaran ikan di stasiun 2 ini bersifat pemencaran individu yang cenderung seragam.

\section{Stasiun 3}

Stasiun 3 terletak di Desa Bajulan dengan tata guna lahan berupa pertanian. Tebing sungai berupa tanah dengan pinggiran sungai masih banyak ditumbuhi semak-semak. Tipe substrat berupa lumpur dan bebatuan padas. Tipe arus cepat serta keadaan airnya jernih sedikit kecoklatan tetapi keadaan sekitar sungai bersih dari sampah rumah tangga. Hasil pengukuran struktur komunitas ikan pada stasiun 3 di Sungai Jerowan yang meliputi kelimpahan relatif (KR), Indeks Keanekaragaman (H'), dan Indeks Morisita (I $\delta$ ) dapat dilihat pada Tabel 3.

Ikan yang tertangkap di stasiun 3 selama penelitian sebanyak 7 ekor terdiri dari 2 spesies yaitu Anabas testudineus dan Rasbora argyrotaenia dengan presentase $57,1 \%$ dari jenis ikan Anabas testudineus (4 individu) dan 42,9\% dari jenis ikan Rasbora argyrotaenia (3 individu). Spesies ikan Anabas testudineus merupakan ikan yang hanya ditemukan di stasiun 3. Jenis ikan ini juga memilki kelimpahan relatif terbesar pada stasiun 3. Hal ini disebabkan karena kemampuan ikan dari spesies Anabas testudineus untuk hidup pada lingkungan yang cenderung tercemar. Menurut Akbar (2012), ikan Betik (Anabas testudineus) merupakan jenis blackwater fish, yaitu ikan yang memilki ketahanan terhadap tekanan lingkungan. Dilihat dari morfologinya, ikan ini memilki labirin yang dapat membantu pada saat kekurangan oksigen maupun lingkungan tercemar. Hasil perhitungan indeks Keanekaragaman Shannon Wiener pada stasiun 3 adalah 0,68 , hal ini menunjukkan bahwa tingkat keanekaragaman ikan di stasiun 3 rendah. Hal ini disebabkan oleh substrat dasar perairan stasiun 3 yang cenderung berlumpur Substrat dasar perairan berupa pasir berlumpur dapat menimbulkan kekeruhan sewaktu-waktu. Pola penyebaran ikan di stasiun 3 ini bersifat pemencaran individu yang cenderung merata.

Tabel 3. Struktur Komunitas Ikan pada Stasiun 3 di Sungai Jerowan

\begin{tabular}{lllll}
\hline Spesies & $\begin{array}{l}\text { Jumlah } \\
\text { (individu) }\end{array}$ & $\begin{array}{l}\text { KR } \\
(\%)\end{array}$ & H' $^{\prime}$ & I \\
\hline $\begin{array}{l}\text { Anabas } \\
\text { testudineus }\end{array}$ & 4 & 57,1 & 0,68 & 1,31 \\
$\begin{array}{l}\text { Rasbora } \\
\text { argyrotaenia }\end{array}$ & 3 & 42,9 & & \\
Jumlah & 7 & & & \\
\hline
\end{tabular}

Menurut Odum (1971), pemencaran individu yang cenderung merata merupakan pola penyebaran yang paling umum terjadi yang dipengaruhi oleh faktor intrinsik (misalnya: reproduksi, sosial dan ko-aktif) dan faktor eksrinsik (misalnya: suhu, udara, kelembaban, cahaya, fisik tanah dan sifat kimia air dapat membatasi distribusi suatu organisme.

\section{Parameter Kualitas Air}

Pengukuran parameter kualitas air di Sungai Jerowan dilakukan sebelum 
pengambilan sampel ikan yang bertujuan untuk melihat seberapa besar pengaruh perubahan kondisi perairan terhadap struktur komunitas sumberdaya hayati ikan di Sungai Jerowan. Pengambilan sampel air dilakukan pada 3 stasiun di sepanjang aliran Sungai Jerowan dengan 3 kali ulangan

Hasil pengukuran parameter fisikakimia perairan selama pengamatan dapat dilihat pada Tabel 4.

Tabel 4. Parameter Kualitas Air Sungai Jerowan

\begin{tabular}{clccc}
\hline No & Parameter & $\begin{array}{c}\text { Stasiun } \\
1\end{array}$ & $\begin{array}{c}\text { Stasiun } \\
2\end{array}$ & $\begin{array}{c}\text { Stasiun } \\
3\end{array}$ \\
\hline 1. & Suhu $\left({ }^{0} \mathrm{C}\right)$ & 29 & 28 & 28 \\
2. & $\begin{array}{l}\text { Kecepatan } \\
\text { arus } \\
(\mathrm{cm} / \text { detik) }\end{array}$ & 7,86 & 30,1 & 18,7 \\
3. & $\begin{array}{l}\text { Kecerahan } \\
(\mathrm{cm})\end{array}$ & 27 & 29,7 & 17,8 \\
4. & pH & 8 & 8 & 8 \\
5. & $\begin{array}{l}\text { DO } \\
(\mathrm{mg} / \mathrm{L})\end{array}$ & 7,5 & 7,64 & 7,77 \\
6. & $\begin{array}{l}\text { TOM } \\
(\mathrm{mg} / \mathrm{L})\end{array}$ & 34,1 & 32,3 & 41,6 \\
\hline & & & & \\
\hline
\end{tabular}

Hasil pengukuran suhu selama penelitian tidak memperlihatkan adanya perbedaan suhu yang besar pada masingmasing stasiun. Kisaran suhu yang diperoleh selama penelitian yaitu berkisar antara $28-29^{\circ} \mathrm{C}$. Kisaran suhu yang diperoleh merupakan kisaran yang umum dijumpai pada perairan tropis dan masih mendukung bagi kehidupan ikan. Menurut Sutisna dan Sutarmanto (1995) menyatakan bahwa kisaran temperatur yang baik bagi pertumbuhan ikan adalah $25-33^{\circ} \mathrm{C}$.

Kecepatan arus Perairan Sungai Jerowan pada setiap stasiun berkisar antara 7,6-30,1 cm/detik. Kecepatan arus pada stasiun 1 termasuk dalam kategori berarus lambat. Kecepatan arus pada stasiun 2 dan 3 termasuk dalam kategori berarus sedang. Hal ini sesuai dengan penjelasan Harahap (1999) dalam Johan dan Ediwarman (2011), bahwa kecepatan arus dapat dibagi menjadi empat kategori yaitu: (1) kece- patan arus $0,25 \mathrm{~cm} /$ detik berarus lambat, (2) kecepatan arus $25-50 \mathrm{~cm} /$ detik berarus sedang, (3) kecepatan arus 50-100 $\mathrm{cm} /$ detik berarus cepat dan kecepatan arus lebih besar dari $100 \mathrm{~cm} /$ detik berarus sangat cepat.

Kecerahan di Perairan Sungai Jerowan pada setiap stasiun berkisar antara $17,8-29,7 \mathrm{~cm}$. Kecerahan terendah terdapat pada stasiun 3 yang disebabkan karena banyaknya limbah pertanian yang masuk ke dalam sungai sehingga mempengaruhi jenis ikan yang tertangkap. Menurut Effendi (2003) bahwa kecerahan air tergantung pada warna dan kekeruhan. Kekeruhan menggambarkan sifat optik air yang ditentukan berdasarkan banyaknya cahaya yang diserap dan dipancarkan oleh bahan-bahan yang terdapat didalam air.

Nilai $\mathrm{pH}$ di Perairan Sungai Jerowan pada semua stasiun adalah 8 atau dapat dikatakan bahwa $\mathrm{pH}$ di Sungai Jerowan cenderung bersifat basa. Hal ini sesuai dengan pernyataan Effendi (2003), bahwa $\mathrm{pH}$ dapat diklasifikasikan menjadi tiga golongan yaitu $\mathrm{pH}=7$ (netral), $7<\mathrm{pH}<14$ (alkalis/basa), $0<\mathrm{pH}<7$ (asam). Menurut Barus (2004), nilai pH yang ideal bagi kehidupan organisme air pada umumnya terdapat antara nilai 7 sampai 8,5 .

Nilai DO di Perairan Sungai Jerowan pada setiap stasiun berkisar antara 7,5-7,77 mg/L. Menurut NTAC (1968) dan Pescod (1973) dalam Akrimi dan Gatot (2002) bahwa suatu perairan tidak terdapat senyawa beracun memilki kandungan oksigen terlarut minimum $2 \mathrm{mg} / \mathrm{L}$. Jumlah tersebut sudah cukup untuk mendukung kehidupan organisme secara normal. Hal tersebut menunjukkan bahwa kadar DO di Sungai Jerowan tergolong baik untuk pertumbuhan dan kehidupan ikan.

Nilai TOM di Perairan Sungai Jerowan pada setiap stasiun berkisar antara 32,3-41,6 mg/L. Menurut Round (1985) dalam Sudaryanti (1991) bahwa kandungan bahan organik terlarut di perairan alami sekitar $50 \mathrm{mg} / \mathrm{L}$. Berdasarkan kadar TOM yang diperoleh dari Sungai Jerowan 
dapat diketahui bahwa kadar bahan organik terlarut di Sungai tersebut tergolong tinggi untuk kategori perairan alami. Tingginya nilai TOM di Sungai Jerowan disebabkan karena banyaknya aktivitas manusia yang menyebabkan masuknya limbah baik limbah rumah tangga maupun limbah pertanian.

\section{KESIMPULAN DAN SARAN Kesimpulan}

Komposisi ikan di 3 stasiun dari Sungai Jerowan terdiri atas 6 spesies yaitu ikan Betok (Anabas testudineus), ikan Belanak (Liza subviridis), ikan Keting (Mystus micrachantus), ikan Wader (Rasbora argyrotaenia), ikan Sepat Siam (Trichogaster pectoralis), ikan Gatul (Gambusia affinis). Nilai keanekaragaman pada seluruh stasiun rendah sedangkan pola sebaran ikan pada stasiun 1 termasuk pemencaran individu yang cenderung acak, stasiun 2 termasuk pemencaran individu yang cenderung berkelompok dan stasiun 3 termasuk pemencaran individu yang cenderung merata. Hasil penelitian menunjukkan bahwa kualitas air di setiap stasiun layak untuk pertumbuhan dan kehidupan ikan.

\section{Saran}

Perlu adanya penelitian lanjutan mengenai kajian biologi ikan yang tertangkap di Sungai Jerowan seperti pola pertumbuhan, faktor kondisi dan kematangan gonad.

\section{DAFTAR PUSTAKA}

Akbar, J. 2012. Pertumbuhan dan Kelangsungan Hidup Ikan Betok anabas testudineus yang dipelihara pada salinitas yang berbeda. Jurnal Bioscientiae. 9 (2) : 1-18

Akrimi \& Gatot. Subroto. 2002. Teknik Pengamatan Kualitas Air dan Plankton di Reservat Danau Arang-arang Jambi. Buletin Teknik Pertanian 7 (2). 2002.

Bahri, F.Y., 2006. Keanekaragaman dan Kepadatan Komunitas Moluska di
Perairan Sebelah Utara Danau Maninjau. Fakultas Matematika dan Ilmu Pengetahuan Alam. IPB: Bogor

Barus, T.A.2004. Pengantar Limnologi Studi Tentang Ekosistem Air Daratan. USU Press, 2004. Medan.

Brower, J.E., dan J.H.Zar. 1990. Field and Laboratory Methods for General Ecology. 3nd ed Wm. C. Brown Publishers. Dubuque, lowa 237h

Effendi, Hefni. 2003. Telaah Kualitas Air. Kanisius. Yogyakarta.

Johan,TI dan Ediwarman 2011. Dampak Penambangan Emas Terhadap Kualitas Air Sungai Singingi Di Kabupaten Kuantan Singingi Provinsi Riau. Jurnal Ilmu Lingkungan. Program Studi Ilmu Lingkungan PPS Universitas Riau.

Odum, E. P. 1971. Fundamentals of Ecology. W. B. Sounders Company Ltd. Philadelphia.

Septiano, Endras. 2006. Keanekaragaman dan Pola Adaptasi Ikan di Daerah Hulu Sungai Ciliwung Jawa Barat. Fakultas Perikanan dan Ilmu Kealutan. IPB: Bogor.

Sinaga, T.P. 1995. Bioekologi Kominitas ikan di sungai banjaran kabupaten banyumas jawa tengah. Tesis. Program Pasca Sarjana. Institut Pertanian Bogor. Bogor

Sudaryanti, S. 1991. Dampak Mekanisme Alat Limnotek 3.1 Terhadap Sebaran Oksigen Terlarut (Studi Restorasi di Perairan Situ Bojongsari, Bogor. Program Pasca Sarjana Instiut Pertanian Bogor. Bogor

Suwondo, E. Febrita, dan F. Sumanti. 2005. Struktur Komunitas Gastropoda pada Hutan Mangrove di Pulau Sipora KabupatenKepulauan Mentawai Sumatera Barat. http://biologi-fkip.unri.ac.id.

Sutisna, D.H. dan S. Sutarmanto., 1995. Pembenihan Ikan Air Tawar. Kanisius, Yogyakarta. 97 hal. 